\title{
Center for Popular Music Research and Popular Music Studies in Serbia: Institutionalization on the musicological margins
}

\author{
Bojana Radovanović \\ Institute of Musicology SASA \\ br.muzikolog@gmail.com
}

\begin{abstract}
The subject of this article is the Center for Popular Music Research in Belgrade, Serbia, founded in 2013. More precisely, this paper deals with the context of the foundation of the Center on the "margins" of musicology, its initial ideas, struggles, realized projects, and some plans for the future. Likewise, it recognizes the pioneering role of the Center's founder, Vesna Mikić (1967-2019), in establishing a platform for popular music studies in Serbian musicology.
\end{abstract}

KeYWORDS: Center for Popular Music Research, Vesna Mikić, popular music studies, musicology, Serbia

\section{Introduction}

Following the establishment of the pioneering classes in popular culture and music in Serbian university-level education, Vesna Mikić (1967-2019) initiated the founding of the Center for Popular Music Research (Centar za istraživanje popularne muzike, CEPOM) in 2013. Creating an organization that brought together researchers whose education was primarily rooted in musicology, Mikić and her young collaborators agreed that CEPOM should have goals such as: researching the practices of popular music, education of (young) professionals in the field of popular music, and arrangement of the activities that contribute to the promotion, preservation, placement, and scientific interpretation of popular culture and music. 
A prominent figure in popular music studies in Serbia, Vesna Mikić was a full professor at the Department of Musicology of the Faculty of Music, University of Arts, Belgrade. (1) Her rich and strikingly interesting array of research topics, as well as her dedicated pedagogical and mentorship work, were of immense importance in gathering a significant number of young researchers around the idea of joint exploration of popular music. Drawing on the innate interdisciplinary nature of musicology, in addition to her scientific and personal interests in popular culture and music, technology, political theory, and sociology, Mikić carved out the beginnings and pathways for a collective that would investigate music in culture, music within its context and music in society.

The main principles of her scientific work are abundantly obvious in her doctoral dissertation, entitled Music in Technoculture, which was defended in 2002 at the Faculty of Music in Belgrade and published two years later. In her own words, "one of the goals of this research was to achieve the interpretation of electroacoustic music of the fin du siècle (meaning end of $20^{\text {th }}$ and beginning of $21^{\text {st }}$ centuries) that could point to the relations of music and everyday (technology permeated) life" (Mikić 2004: 234). As it turned out, dealing with technology and with the culture immersed in it demanded a vast and working knowledge not only of current and historical technological inventions and their applications in art and electroacoustic music, but also of popular culture and music. This research was unprecedented in Serbian musicology, and it very quickly led to opening new horizons to the generations of students that had the privilege of attending Mikić's classes. A little over a decade later, she used her position and soft power in a way she thought appropriate and best for her musicological offspring. She often liked to say to her students: "This is the best I could do, and you can do whatever you see fit with this platform; I will be here to support you".

The sudden and surprising passing of the Center's founder and director left her young collaborators and students painfully even more aware of the role and the potential of this organization. Looking back on the Center's first years and initial undertakings, my aim here is to shed light on the struggles, ideas, projects, and several plans of this collective. Thus, I will first give some insight into the context of popular music studies in Serbia, especially concerning musicology. Second, parallels between the Center for Popular Music Research and other institutions that came beforehand will be drawn. Here, I will take into account the postulates of Peter Wicke's organization of the same name, which was founded in the early 1980s in East Berlin. Finally, I will present recent projects and achievements of this organization, in addition to looking into the plans and projects that are currently in motion.

\section{Popular Music Studies and Musicology in Serbia}

Although there is a notable rise in interest in popular music studies in Serbia since the 1990s (Medić 2019: 215), it can be said that this trend was not as prominent in musicology as in other academic fields such as history, anthropology, or sociology. Furthermore, given the postulates of conventional musicology, which originates in studying highly canonized Western European art music, it seems as though the official response to new tendencies concerning popular music research can only be negative, or, in other words, correspondent with the prevalent attitude of the institutions of the time. 
Philip Tagg, for example, has been outspoken and unapologetic when it comes to the misunderstanding between popular music studies and musicology, writing that musicology

(...) may have developed valid theories about harmonic narrative in European art music, but it has (...) been intellectually about as open-minded as religious fundamentalism in dealing with anything outside its own restricted frames of reference. Despite the radical challenges presented by first ethnomusicology over a century ago, then by the sociology of music, and latterly by popular music studies, its followers still often seem to believe in universal values of aesthetic excellence based on a canonic repertoire of work used by a minority of the population over a very limited number of years in the world's smallest continent. (Tagg 2011: 7).

Admittingly, over the last couple of decades we have witnessed tremendous growth in scholarly knowledge about an almost overwhelming range of topics related to popular music from around the world, with myriad diverse and mesmerizing approaches. This was pointed out in one of the responses to Tagg's article (see Kassabian 2013), along with some other ways in which popular music studies made notable progress and got into the mainstream of contemporary musicology. It must, however, be acknowledged that, in the context where easy ("laka"), "zabavna muzika",(2) and popular music are still widely considered as "bad words" in musicology, the first efforts to make a change in this mindset are immeasurable. To the old guard, or traditionalists, this is something that will hardly ever change even today, popular musicologists in Serbia (and possibly elsewhere) and their scholarly work are subjected to somewhat condescending view by their peers.

The history of Serbian musicology officially began in 1948 when the Department for Music History and Music Folklore at the Faculty of Music (at that time, Music Academy), and the Institute of Musicology of the Serbian Academy of Sciences and Arts, were founded. In terms of musicological research, for decades the main subjects were history of Serbian and Yugoslav art music, and contemporary Serbian and Yugoslav music in relation to European/Western centers, as well as the history and contemporary sacral music practices. Popular music was considered not valuable enough, intended only for entertainment and as a pastime, and therefore not suitable for musicological scrutinization. Postmodern composers, in Serbia and elsewhere, introduced popular music as an equally valuable source of inspiration. During the last decades of the $20^{\text {th }}$ century, this change in art music practices also brought up a new demand upon musicologists. Going forward, as seen in Mikić's dissertation, in order to truly understand contemporary composers it almost became obligatory for a musicologist to be acquainted with mechanisms and technologies of the (popular) music industry, sound production, and modes of promotion. This was also the time when, on the musicological scene of the world, studies in popular music became more prominent, 'louder', and more influential.

In the context of Serbian musicology, the initiation of the change began with the pedagogical and scientific work of Vesna Mikić during the first decade of the $21^{\text {st }}$ century. Along with research on the Eurovision Song Contest and popular music of the former Yugoslavia (3) she created courses for Ph.D. students at the University of Arts such as "Theory of Popular Art and Culture" in 2003, and later "Popular Music: Theory" and "Popular Music: Genres" at the Faculty of Music. This enabled students who were interested in popular music to dive into this field of study - albeit not until the graduate level of studies - and soon enough formed the critical mass needed for the next step in developing a platform for popular music studies. It is 
worth noting that, as a truly caring and devoted professor, Vesna Mikić envisioned an organization which would give space and opportunities for her colleagues who are at the beginning of their careers.

Within this framework, CEPOM's founders estimated that the climate within official musicological institutions did not yet agree with the research inclined towards popular music studies. For this reason, on the very margins of their Faculty, a professor and her students decided to form an association that would not enjoy the formal support of the institution, but would, in exchange, gain a certain degree of autonomy and freedom. To this day, the fact that CEPOM is officially an association of citizens - an NGO if you will - indicated the hardships encountered in the acquisition of funding and overall financial support and structure. Competing with all the other NGOs, as well as with state cultural institutions, this collective is dedicated to do its work primarily "for the glory", "exposure", the advancement of science, and the love of research - which appears strikingly similar to the work of numerous independent musicians today and throughout history.

Naming it the way she did, Vesna Mikić created this organization with Peter Wicke's Center for Popular Music Research (Forschungenzentrum Populäre Musik) in mind. Founded in 1981 at Berlin's Humboldt-University in the German Democratic Republic by, as Wicke recalls, "attaching a sign to a door without asking anyone" (Wicke 1994: 67, in Hemming 2019: 34), certain parallels can be drawn even in the determining act of opening a new chapter in musicological history. Further commonalities at the base of both Centers include a tendency towards development of research in the popular music field; encouragement of theses and dissertations on popular music; cooperation with various educational and scientific institutions, as well as the music industry and musicians; and, finally, promotion and presentation of the research results (cf. Wicke 1997: 153). Even though the Serbian Center is not an institution of education and is, therefore, not directly responsible for students' thesis and dissertation management (given the fact that research institutes and organizations do not have authority of that kind in Serbia), the aforementioned courses that Mikić founded at the Faculty of Music and the University of Arts encouraged many generations to embark on the path of popular music research.

As noted, the investigation of popular music demands understanding and recognition of a complex socio-cultural process (Wicke 1997: 154). It develops awareness of the interconnectedness and fluidity of crucial underlying elements and concepts such as technology, music industry, (youth) culture, commercial music production and promotion, music journalism and fandom, sound and genres, and many more that are invaluable in said process. With this in mind, CEPOM began its research in 2013, branching out to various factors and practices of popular music phenomena.

\section{CEPOM's projects, achievements, ideas}

Over the years, CEPOM developed several research projects whose results were presented online and in traditional media - on the organization's website and social media profiles, and in several radio interviews - as well as in a series of lectures, discussions, and public events, mostly held in Belgrade.

In 2013, right after the initiation of the organization, the Center began a longstanding project named "Music Scenes in Serbia: Popular Music Practices" (4) led by Vesna Mikić. The project was aimed toward researching musical scenes in several cities (Belgrade, Novi Sad, Inđija, Zaječar, Paraćin) in order to contribute to 
the decentralization of musical spaces and to gain a more realistic insight into popular music in Serbia. With a hint of autoethnography, these cities were chosen for one simple reason - the researchers originated from those places and were connoisseurs of some of the intertwined musical scenes that were the focus of this exploration. Musicologist and sociologist Maja Vasiljević designed a questionnaire for all the musicians-participants. What drove CEPOM towards this particular subject was the fact that, given the situation within mainstream media, not enough attention or opportunities were being given to the popular music practices of young, somewhat underground, or minority groups. Mapping and recording the activities of local artists and bands included in the local jazz, hip-hop, experimental, alternative, and metal scenes turned out to be the primary incentive of this project. Carried out by Nikola Pejčinović, Milan Milojković, Marija Maglov, Adriana Sabo, Milan Jančurić, and Radoš Mitrović, this investigation set the base of the project's sequels to come.(5) Pejčinović investigated the alternative scene in Kruevac by including bands and musicians coming from various genre backgrounds (ska, dub, post-rock, jazz, gothic rock, post-punk, darkwave, hardcore). Milojković delved into the hip-hop scene of Zaječar, a research project which resulted in coining the genre of "Zaječarski rep" (Rap from Zaječar). On her own, Maglov explored the music scene of Inđija, interviewing the only three active bands, which belong to different genres, and together with Jančurić, she researched the jazz scene of Novi Sad. With respect to another genre, the Noise scene turned out to be particularly active in Novi Sad, even though dedicated venues are practically non-existent, as demonstrated by Adriana Sabo. Finally, Mitrović investigated (a part of) the rap scene in Belgrade. Combined, the findings of these examinations of the terrain showed the lack of infrastructure and support for independent and small musicians coming from different genre-backgrounds and parts of the country. Music scenes in all the included cities demonstrated some level of inter-genre or inter-scenic collaboration, whether this meant sharing the venues and practice spaces, or even fans and publishers. New research questions were emerging with respect to the functioning of these fluid and interconnected structures, showing that forms of youth culture that are in any way alternative or underground did not have enough space or resources, which would more often than not cause the dissolution of the bands in question.

As mentioned above, the results of the initial research were promoted via various media channels and presented within the cycle of lectures dubbed "Music Scenes in Serbia" held at Gallery of Students Cultural Center (Novi Beograd) during the spring and summer of 2015.

Having different actors of a music scene in mind, the next instalment of the overarching project addressed the role of music festivals within music scenes (local, translocal, and virtual). This step towards festivals seemed logical not only from the viewpoint of the music industry components, but it also seemed to have organically emerged from the responses of the musicians included in the first phase of the "Music Scenes in Serbia" project. From the musicians' perspective, festivals were a crucial factor for representation and exposure; a place where it was possible to perform for a larger audience, to connect with other artists, fans, and organizers, and to actively work towards a state of flow and to experience exchange between different generations of musicians, their audience, and the other factors of the music industry (Radovanović 2018: 440). The project entitled "Musical Scenes in Serbia: Festivals as an Aspect of Popular Music Practices" (2016/2017) thus included several important festivals and festival stages in Serbia such as the Exit festival, the 
Serbian Underground Festival, the Niville, Belgrade Jazz Festival, the Arsenal festival, and the Festival of Street Artists in Novi Sad, focusing on the place and prominence of Serbian and local artists in their respective programs. This was also an opportunity to explore how festivals that belong to diverse music scenes (metal, jazz, pop, alternative) are organized and funded. The research, which included interviews with festival organizers and the scrutinization of festival programs, was executed by Ana Đorđević, Katarina G. Lazarević, Marija Maglov, Nikola Pejčinović, Katarina Lazarević, and Bojana Radovanović. By comparing our individual results, we have uncovered several recurring issues concerning (inter)national festivals and Serbian musicians on their stages, which are described in depth in the text on CEPOM's website. On a slightly different note, when it comes to jazz festivals, due to the longer tradition and somewhat peculiar mechanisms of functioning of the scene, we observed that: 1) visibility, exposure, and symbolic capital rather than financial compensation are, in general, offered to young and aspiring artists; (2) festivals are crucial factors in maintaining alternative music scenes in Serbia, as opposed to the significant media support given to the mainstream music; (3) the effect of pilgrimage (Dowd, Liddle and Nelson 2004:149150) can be observed, whether as an intensive event of a certain scene (such as the Serbian Underground Festival), or as a genre in itself (seen mostly in summer festival series); (4) the examined festivals are becoming increasingly commercial over the years, which, in return, causes the neglect of certain genres and local performers in favor of bigger names; (5) each and every one of the festivals we observed plays an important role in cultural tourism, and therefore, obtains significant amounts of financial support from the local and national authorities and cultural institutions such as the Ministry of Culture (Radovanović and Maglov 2018). All of these findings were disseminated via public events (held, again, in cooperation with the Student Cultural Center of Belgrade), lectures, conference presentations, as well as scientific and other articles. (6)

As a project coordinator, Vesna Mikić noticed a tendency among her associates towards studying alternative, underground, and independent music practices. From the perspective of the groundbreaking popular music research that was done in sociology, history, or anthropology, phenomena such as turbofolk, that is, specific mainstream music genres from the Balkans, are those that should be examined and contextualized.(7) However, as Mikić highlighted, given the opportunity to study popular music, her students - perhaps unconsciously and empathetically - decided to give voice to those practices that could be viewed as music on the margins. Mainstream music, for the time being, remains outside of the musicological scope, and one cannot but wonder why this is the case. It could be that there is still some residue of the traditional musicological worldview; alternative or underground music is often thought to have more symbolic and artistic value than the mainstream music, such as turbofolk, a hybrid genre that flourished throughout the 1990s. Turbofolk also, along with certain more recent genres, additionally carries the weight of being associated with certain lifestyles and values that are not fondly remembered by some. This could be one of the reasons why collaborators on this project used their freedom and empowerment in researching popular music, in addition to their position as a (scientific) authority, to promote the advancement of more marginalized practices, at least in the first years of the Center's work. (8)

Besides the main project, the Center's collaborators also completed and initiated various other activities and publications. Worth mentioning is the booklet S/ušajmo ekološki ("Let's listen ecologically") by Biljana Leković and Boris Jokanović, which is dedicated to the youngest audiences. Namely, this e-booklet(9) is fashioned in a 
way that gives basic and beginner knowledge, ideas, and even assignments about listening, acoustic ecology, and the sounds surrounding people. With this publication, CEPOM also took a step in the direction of sound studies and sound ecology, fields of study which are, at the moment we are living in, rapidly coming to the forefront of scientific interest and urgency.

Furthermore, attesting to rising interest in another provocative branch of popular music studies, that is, the study of the Eurovision Song Contest, in June 2015 CEPOM's collaborators participated in a conference entitled Musical Diversity and Cultural Identities in the History of the Eurovision Song Contest - Recapitulating ESC 1956-2015, held in Graz, Austria, and organized by the Institute of Musicology of the University of Graz (Institut für Musikwissenschaft, Karl-Franzens-Universität Graz). As an invited speaker, Vesna Mikić presented her paper "Rock me - Lane moje: transitory identities in Yugoslavia and the West Balkan" which, in a condensed and effective way, gave an insight into the thoroughness of her approach to layered research of the Eurovision Song Contest in the context of European studies. At the same time, her younger colleagues participated in poster presentations. At the time, students of doctoral and master studies in musicology at the Faculty of Music (and now Ph.D. candidates), Adriana Sabo, Marija Maglov, Ana Đorđević, and Bojana Radovanović, took part in a poster discussion with students from the University of Graz about stereotypes and exaggeration in ESC, trends and traditions, and political background of the competition. These analyses were the result of another course Mikic initiated at the Faculty of Music within the Jean Monnet Module "Musical Identities and European Perspective: An Interdisciplinary Approach", named "Insieme - Unite, unite Europe!": Introduction to the Eurovision Song Contest Studies (2015-2017). (10) For doctoral and especially masters students who attended these classes, they most definitely turned out to be a safe way towards popular music studies through studying concepts such as festivals, song competitions, contemporary media, and national (pop) music identities and politics in music.

\section{Concluding remarks: looking ahead}

Specific contacts and events throughout the years led CEPOM on the road to some new and exciting ideas and their fruition. For example, after participating in a public discussion in April 2018 dedicated to debate about the relationship between folk/ethnic music and pop/rock in Serbian and Yugoslav popular music history, the Center began a collaboration with Rock Museum (Rok muzej) in Belgrade. This association, founded by Miroslav Cvetković Cvele, widely known as a bassist of a famous Serbian rock band Bajaga i instruktori, initiated the archiving of photographs and personal fan archives that included all sorts of valuable paraphernalia related to rock fandom in Serbia. Through personal archives and official sources, histories of festivals such as Youth Festival in Subotica should be scrutinized in the future. With limited financial support, these projects are still in a conceptual phase and are currently paused because of the situation brought about by the grave illness and passing of the Center's founder and director. In this position Vesna Mikić is succeeded by Biljana Leković, a docent at the Department of Musicology, Faculty of Music in Belgrade, who graduated under Mikićs mentorship.

One of the final larger-scale undertakings that started unfolding during 2019, but was postponed amidst the COVID-19 crisis of 2020, was an international and 
interdisciplinary conference on popular music in the Balkans. The first of its kind in our region, this event was organized in collaboration with the Institute of Ethnology and Anthropology, and the Department of Ethnology and Anthropology of the Faculty of Philosophy in Belgrade. A large number of proposals from more than 15 countries confirmed the significant attention and eagerness which an event such as this one generated. As is highlighted in the call for proposals,

On the one hand, the attribute "Balkan" refers to a geographical area whose boundaries are not always clearly defined. On the other hand, the Balkans, although highly diversified culturally, are often perceived, internally as well as externally, as a bearer of "authenticity", a bearer of an authentic culture, an authentic sound included (Popular Music of the Balkans 2019).

As such, and on this occasion, music from the Balkan countries provoked numerous scientists and researchers from different disciplines to try and give some answers to questions concerning music, identity politics, media, popular music between the local and the global frameworks, and many more. Continuing with the preparations even in the toughest of times, this conference will be held at the earliest practicable opportunity and in honor of Vesna Mikić. In the meantime, CEPOM will be working on preparation and publication of Mikić's long-awaited book, Faces of Serbian Music: Popular Music (in Serbian),(11) which will not only commemorate the Center's founder but also pave the way for the future scientific research of popular music in Serbia on the intersections of popular music studies and musicology.

\section{Endnotes}

(1) For a full text on Vesna Mikić's scientific, pedagogical, and organizational achievements, see Leković 2019.

(2) During the late 1950s and early 1960s, the term "zabavna muzika" signified Yugoslav domestic popular music of all genres (Mikić 2016: 272). See also Mikić 2017.

(3) See, for example, Mikić 2007a, 2007b, 2008a, 2008b, 2009. After the debut of Serbia and Montenegro in 2004 after the sanctions with Željko Joksimović's song "Lane moje", and especially following the Serbian victory in 2007, the scientific and general public were intrigued. On that wave, Vesna Mikić presented and published several papers on the topic of the popular "ethno-pop ballad" that marked the 2010s ex-Yu entries in ESC, thus discussing the subject of national and folk identities of the former Yugoslav republics expressed and (re)created through popular music. Furthermore, delving into the past of her own home country (she always highlighted that she still felt and carried herself as a Yugoslavian), she wrote about the biggest music stars of SFRY, among which was Zdravko Čolić, the "guru of pop ballad" (See Mikić 2007a).

(4) See: http://www.cepom.org/projekti.html

(5) All of the recordings and follow-up text are available on CEPOM's website: http://www.cepom.org/muzi269ke-scene-u-srbiji.html

(6) In addition to the Center's lecture dedicated to Serbian musicians on the (inter)national festival stages, held in New Gallery of Student Cultural Center in June 2017, Bojana Radovanović also presented a part of her research on Serbian Underground Festival at the scientific conference "Anthropology of Music", held at Belgrade's Faculty of Philosophy in March 2018. Interviews, follow-up texts and articles (in Serbian) are available on the following link: http://www.cepom.org/muzicki-festivali-u-srbiji.html. 
(7) For example, one of the first defended MPhil dissertation on a popular music subject was Ivana Kronja's work on turbofolk (1998), which was published in 2001 as the monograph Smrtonosni sjaj: masovna psihologija i estetika turbo-folka ("The Deathly Glow: Mass Psychology and the Aesthetics of Turbo-Folk") (Medić 2019: 2016). For some "fresh" anthropological readings of turbofolk and its contemporary forms, see Kulenović and Banić Grubić (2019).

(8) This is also noticeable in the Serbian musicological output outside the Center (see Medić 2019). Turbofolk, together with some other music practices that are closer to folk music (narodna muzika /"folk music"/, Urban folk music, and the like), are more often in the scope of Serbian ethnomusicological research (see, for example, Nenić 2009, Dumnić 2019), or foreign researchers (see Baker 2008).

(9) Available on: http://www.cepom.org/sluscaronamo-ekoloscaronki.html

(10) See the syllabus for the course here: http://www.midep.ac.rs/?page_id=317

(11) In the near future, CEPOM also plans to expand its publishing activities by publishing the first monograph about Vojislav Bubiša Simić, a famous Serbian jazz musician, composer, and conductor, written by Katarina G. Lazarević.

\section{Acknowledgements}

This research was carried out within the Institute of Musicology of the Serbian Academy of Sciences and Arts, which is funded by the Ministry of Education, Science and Technological Development of the Republic of Serbia.

\section{References}

\section{Bibliography}

Baker, C. 2008. When Seve met Bregović: Folklore, turbofolk and the boundaries of Croatian musical identity. Nationalities Papers 36 (4): 741-764. https://doi.org/10.1080/00905990802230514

Dowd, T., Liddle K. and Nelson J. 2004. Music Festivals as Scenes: Examples from Serious Music, Womyn's Music, and SkatePunk. In A. Bennet and R. A. Peterson Eds. Music scenes: Local, Translocal and Virtual. Nashville: Vanderbilt University Press: 149-167.

Dumnić Vilotijević, M. 2019. Urban folk music and cultural influences: Labels for narodna muzika (folk music) in Serbia in the twentieth century. In M. Dumnić Vilotijević and I. Medić Eds. Contemporary Popular Music Studies. Proceedings of the International Association for the Study of Popular Music 2017. Wiesbaden: Springer VS: 39-50.

Hemming, J. 2019. Popular music studies in Kassel and the Germanies. In M. Dumnić Vilotijević and I. Medić Eds. Contemporary Popular Music Studies. Proceedings of the International Association for the Study of Popular Music 2017. Wiesbaden: Springer VS: 27-38.

Kassabian, A. 2013. You Say Invisible, I Say Ubiquitous: A (Formally Former) Student's Response to Philip Tagg's 'Caught on the Back Foot: Epistemic Inertia and Visible Music'. IASPM@Journal 3 (2): 86-95. 
Kulenović, N. and Banić Grubić A. 2019. 'Turbo-folk Rocks!': New Readings of Turbo-folk. Issues in Ethnology and Anthropology, 14(1): 47-78. https://doi.org/10.21301/eap.v14i1.2

Leković, B. 2019. Steps and Traces of Vesna Mikić (1967-2019), INSAM Journal of Contemporary Music, Art and Theory, 2 (3): 10 - 13.

Medić, I. 2019. Rock music videos in Serbia since the 1990s: The curious case of Jarboli. In M. Dumnić Vilotijević and I. Medić Eds. Contemporary Popular Music Studies. Proceedings of the International Association for the Study of Popular Music 2017. Wiesbaden: Springer VS: 215-224.

Mikić, V. 2004. Muzika u tehnokulturi. Beograd: Univerzitet umetnosti u Beogradu. 2007а. Први и последњи - Здравко Чолић- гуру“ поп Баладе.

Интернационални часопис за музику Нови Звук, 30, II: 105-113. 2007b. Eurovision Song Contest - Serbian Victory. Nutida Musik 3: 32-38. 2008a. The Way We (Just Me, Myself and I) Were: Recycling (National) Identities in Recent Popular Music. In T. Marković and V. Mikić Eds. Musical Culture \& Memory. Belgrade: Department of Musicology, Faculty of Music, University of Arts in Belgrade: 173-182.

2008b. Folklore as a Vehicle for (Re)Construction of 'Unified Space' or How to Turn a Fawn into a Wolf and Then into a Dove and not to end up with some kind of Mythological Creature? In M. Veselinović-Hofman Ed. Musical Folklore as a Vehicle? Belgrade: Serbian Musicological Society, Department of Musicology and Department of Ethnomusicology, Faculty of Music in Belgrade: 69-77.

2009. Институционализација жанра популарне музике у оквиру COКОЈ-а. In V. Mikić and T. Popović-Mlađenović Eds. Тематски потенцијали лексикографских јединица о музичким институцијама. Београд: Катедра за музикологију ФМУ: 115-123.

2012. Ex-Yu nostalgia, nExt-Yu Realities? Some popular music strategies in former Yugoslavia spaces. In V. Mikić et al. Eds. Between Nostalgia, Utopia, and Realities, Musicological Studies: Collection of Papers. Belgrade: Department of Musicology, Faculty of Music, University of Arts: 394-600. 2016. Neither/Nor: Articulating Constant/Continuous Transition in Serbian Popular Music. In M. Veselinović-Hofman et al. Eds. Music: Transitions/Continuities. Belgrade: Department of Musicology, Faculty of Music, University of Arts in Belgrade: 269-276.

2017. Zabavna muzika. In D. Horn, J. Shepherd and P. Prato Eds. Bloomsbury Encyclopedia of Popular Music of the World, Volume XI: Genres: Europe. London: Bloomsbury Academic: 828-832.

Nenić, I. 2009. Roze kiborzi i /de/centrirane ideološke mašine: Preobražaji muzičke culture (turbo)folka. Genero: Časopis za feminističku teoriju I studije culture 13: 63-80.

Radovanović, B. 2018. Festival srpskog podzemlja: "muzička scena u malom". Etnoantropolo ki problemi 13 (2): 439-453. https://doi.org/10.21301/eap.v13i2.8 
Tagg, P. 2011. 2011. Caught on the Back Foot: Epistemic Inertia and Visible Music. IASPM@Journal 2 (1-2): 3-18. http://dx.doi.org/10.5429/2079-3871(2011)v2i1-2.2en

Wicke, P. 1997. Research Center for Popular Music (Forschungszentrum Populäre Musik), Humboldt University, Berlin. The World of Music 39 (2): 153-155.

\section{Web Sources}

Center for Popular Music Research. CEPOM. 2013. http://www.cepom.org/ Accessed: 15 March 2020.

Popular Music of the Balkans Conference. 2019. http://www.popmusicbalkan.com/en/index.html Accessed: 20 January 2020.

Radovanović, Bojana i Marija Maglov. 2018. Muzičke scene u Srbiji - domaći izvođači na festivalima“. Centar za istraživanje popularne muzike, dostupno na: http:// www.cepom.org/doma263i-izvodja269i-na-festivalima.html 